\title{
Mikhail Larionov and Roger Fry: to the History of Sergei Diaghilev's Ballets Russes in England in Late 1910s
}

\author{
Ekaterina Vyazova \\ Department of Fine Arts and Architecture \\ State Institute for Art Studies \\ Moscow, Russia \\ E-mail: sviazov@mail.ru
}

\begin{abstract}
The following article deals with how Sergei Diaghilev's Ballets Russes enterprise was perceived in England after the First World War, with a focus on ballets choreographed by Leonide Massine and designed by Mikhail Larionov. Larionov's collage Homage to Roger Fry (1919, Victoria \& Albert Museum, London) served as a point of departure in this research [1]. The history of this work and its possible interpretations are of interest not only in themselves: the context in which the Homage appeared had to do with the specifics of Diaghilev's ballets of the second postwar period, which turned out to be in line with relevant problems of British criticism and art of the second half of the 1910s.
\end{abstract}

Keywords-Mikhail Larionov; Roger Fry; Sergei Diaghilev; Ballets Russes; national art

\section{INTRODUCTION}

The Victoria \& Albert Museum of London holds Mikhail Larionov's collage Homage to Roger Fry[2] (Il. 1). Dating from 1919, this work has been mentioned fleetingly in British studies of Russian art [3], but has not been reproduced in major Russian writings on Mikhail Larionov. Nevertheless, its history is not merely curious in itself, but is connected with a highly interesting stage in Sergei Diaghilev's Ballets Russes history and, more broadly, with the perception of Russian art in postwar Europe.

The late 1910s - early 1920s witnessed the peak of Diaghilev's postwar fame and the triumph of Ballets Russes in London. If previously English magazines had used to publish reviews of Moscow and St. Petersburg exhibitions for instance, until 1917 Studio regularly published reviews of the "World of Art" and "Union of Russian Artists" expositions in its Studio-Talk section - now critics focused mostly on Diaghilev's productions. The English press was flooded with publications about the Russian ballet, David Bomberg published his book Russian Ballet (1919) with Vorticist illustrations, and exhibitions of stage designs by Russian artists were held. [4]The Observer regularly carried announcements of Diaghilev's productions, detailed reviews of the already performed ballets, brief surveys of the Ballets Russes history and interviews with Diaghilev and the choreographer Leonid Massine. In 1921, The Observer reporter opened his article "The Return of the Russians. Ballet as Spectacle" as follows, "There is only one fault that can, with any justice, be urged against M.Diaghileff"s ballet - this great spectacle that ranges so triumphantly over the capitals - and that fault is, the effect it has on other people. Its intoxication is almost instantaneous, is devastating when at its height, and leaves a lasting effect. Under its influence, reasonable and charming people have been known to become maniac; and as the complaint is not officially recognized as contagious, they are hardly ever guaranteed" [5]. Riding the tide of general enthusiasm, Roger Fry again addresses works of Larionov, whom he knew from the time of the "Second Post-impressionist Exhibition" of 1912. Larionov and Goncharova not merely contributed to that famous exposition staged by Fry: together with Boris Anrep, Larionov helped to select works for the Russian section of the exhibition. Seven years later, in February 1919, Fry organised the first solo exhibition of Larionov in England, displaying eleven of his stage sketches at the "Omega Workshops" [6] and in March published an article, "M. Larionov and the Russian Ballet", in the Burlington Magazine[7].The exhibition and article came in the wake of the Diaghilev company's London tour that lasted from 5 September 1918 to 20 December 1919 [8] and largely contributed to the popularity of both Larionov and Diaghilev's Ballets Russes in England. Obviously, it was in gratitude for that support that Larionov produced his Homage to Roger Fry [9].

The Homage apparently was first published in the catalogue The Omega Workshops: Alliance and Enmity in English Art, 1911-1920 of the exhibition that the Anthony d'Offay Gallery held in 1984. [10] It was initiated and inspired by descendants of the key figures of that exposition - Pamela Diamond, daughter of Roger Fry, and Angelica Garnett, daughter of the "Omega" and "Bloomsberry" group artists Duncan Grant and Vanessa Bell, sister of the writer Virginia Wolfe. The bulk of the works on show came from their collections. Larionov's collage made its way to the exposition directly from the collection of Roger Fry. The catalogue opens with Pamela Diamond's memoirs about the "Omega Workshops" that existed for a mere seven years 
(from 1913 to 1919) yet became a bright episode in the annals of British modernism ${ }^{1}$.

It is rather hard to place the collage dedicated to Fry into the context of Larionov's works of the second half of the 1910s and early 1920s. At that time Larionov was engrossed primarily in theatre projects and put the easel on the back burner. Nevertheless, there is a curious parallel to the Homage among his graphic sheets of that period - a gouache, The Equilibrium of Dance, dating from the second half of the 1910s and included in the pochoir album L'Art Theatral Decoratif Moderne, 1919. (Il. 2.) The compositions of both the gouache and the collage that are obviously connected with Larionov's Rayonnist period are based on the intersection of diagonals and geometrical shapes. A triangle with its sharp angle directed at the upper right-hand corner of the sheet is at the centre of the two compositions. It is crossed by a diagonal that is topped by a "flag" in The Equilibrium of Dance and the word "Fry" in the Homage. This rightward movement is balanced out by another triangle slanted leftward or a semi-circle, with shapes at the base of the vertically oriented composition imparting stability to this fragile balance. The blue and brown triangles that replicate the shape of the upper triangle serve as such a base in the Homage whereas in the Equilibrium of Dance it is the straight line and the semi-circle that likewise echo the shape of the upper figure and serve as the base. The coquettish scroll of a head in The Equilibrium of Dance is replaced by a ribbon bow-knot in the Homage.

The meaning of the inscriptions on the ribbon - Tel. 946 Neuilly and Fleurs Marteau — is not quite obvious. A. Parton calls the collage The Portrait of Roger Fry and believes that the bow-knot is a hint at Fry's bow-tie [11]. This interpretation does not sound convincing. For one thing, Larionov has no portraits of such a completely abstract type. For another, the bow-knot hardly looks like a tie but rather like a simple ribbon used to tie flower bouquets. Furthermore, it is noteworthy that in Larionov's works inscriptions and paste-ons are nearly always object specific. For instance, pieces of bills of the productions of Le Coq d'Or and The Fan designed by Natalia Goncharova and bits of newspaper reviews with the titles Ballets Russes, Theatre, De L'Opera are pasted into the Portrait of N.S. Goncharova (1915, STG). In the Homage, too, Larionov may have used the address and telephone number of a flower shop in the Neuilly commune of Paris, pinning its card to his composition and thus likening it tongue-in-cheek to a bouquet ceremoniously presented to Fry [12].

The Equilibrium of Dance has another title - The Portrait of L. Massine[13].Thus, the two sheets share not only the time of their execution and similar compositional methods, but also the theme - Diaghilev's ballet productions: after all, both the exhibition organized by Fry

These memoirs relate a curious episode connected with the Ballets Russes. Pamela Diamond recalls that her father had taken her along to a reception organised for the Ballets Russes company. Roger Fry wore "exotic pajamas" designed by himself (it was on the exhibition display) while the "Omega" artist Edward Wolfe was dressed in a costume that he had borrowed from the Russian ballet company and that "had inspired him to dance with abandon". and his article dealt with Larionov's works for the theatre. It was precisely in the theatre context that Larionov mentioned Fry in his 1918-1919 manuscript summary of his grand history of the world theatre that was to be published in several volumes by the G. Povolotsky publishing house. Its section on modern English art mentioned two names: that of Lord Berners, diplomat, artist and composer, and Roger Fry [14].

In my opinion, the context, in which Larionov produced his Homage to Robert Fry, as well as his stage experiments that elicited interest among English critics, merit special research. Before expounding on the British perception of Larionov's productions for the Ballets Russes of Diaghilev, a small digression is called for to describe the peculiarities of Diaghilev's ballets after the war and the significance of that period for the overall evolution of the Ballets Russes.

\section{II. 'RUSSIAN THEME' IN TwO PERIODS OF THE BALLETS RUSSES}

Traditionally, the history of Diaghilev's enterprise, which existed from 1909 to 1929 , is divided into two periods. The first prewar period was the Russian theatre on the European stage as a direct extension of the "World of Art" project created by its participants Leon Bakst, Alexandre Benois, Alexander Golovin and Nikolai Roerich. The specifics of the second, postwar period were determined by collaboration with European avant-garde artists and consistent integration into western culture. However, in his 1919 interview to The Observer[15] Diaghilev himself divided the history of Ballets Russes into three periods, by choreographers: "the epoch of Fokine, the epoch of Nijinsky and the epoch of Massine", at that time giving preference to the latter period as the "most innovative" one. Indeed, despite the common European vector, it was the joint projects of Larionov and Massine that largely shaped Diaghilev's postwar seasons and the new concept of "national identity", which gives an insight into the exceptional role Diaghilev's postwar ballet played in world culture. To understand how logically Larionov's and Massine's "national" ballets fit into the common European trend of Diaghilev's postwar seasons, a few words should be said about a curious paradox in the history of Diaghilev's artistic ventures, in particular, how each of Diaghilev's "Russian project" - an exhibition, concert, opera or ballet season - was a direct consequence of his consistent Europeanism.

The continuity of various periods of Ballets Russes as an integral project, guided by one will, was aptly noted by some European critics. One of them was Robert Brussel, Le Figaro's French correspondent, who wrote reviews about the first Ballets Russes seasons in Paris. In 1930, he published a summing-up article "Avant la Féerie" in a special issue of La Revue Musicale dedicated toLes Ballets Russes de Serge Diaghilev. This is how Brussel defined Diaghilev's artistic objectives:

"What did he wish? Stated simply, these three things.To reveal Russia to itself, to reveal Russia to the world, to reveal the new world to itself. And that in the simplest, most direct and easiest manner, through painting and music, and only 
later did he dare to say, 'and through the dance'. What did he not wish? That Russia should be deemed something exotic, with nothing to offer Western eyes but the contrasts of some picturesque bazaar. Nothing exasperated him more. <.. >

"This national pride and threefold aim inspired his every act, and explains both his aesthetic deviations, and his fluctuating ideals.

"Better that most, he had realised that one must go forward breakneck, to make sure of not being out-distanced, that it was of the utmost importance to hurry forward.

"He had, therefore, to move fast, and having recalled Russia to the Russians, and the new Russia to the world, to exchange his Russian clothing for clothing that was European, turn polyglot, dominate all discussion, and become the arbiter of the artistic destinies of two continents."[16]

Diaghilev's first large-scale exhibitions of Russian art were directly connected with the pro-western enlightenment programme of the World of Art magazine, namely, the desire to consider Russian culture in the European context for the first time so consistently demonstrated to the domestic readers. To this end, Russian art itself had to be presented not only as a school in itself, but primarily as a living process subordinate to a certain logic of development.

This was the aim of the legendary "Historical and Art Exhibition of Russian Portraits"in the Tauride Palace in 1905 and the exhibition "Two Centuries of Russian Painting and Sculpture" in the Paris Salon d'Automne of 1906, which helped the public to rediscover whole periods of Russian visual art. This was how Diaghilev defined his main goal in the Paris exhibition catalogue, “...12 halls make up an ensemble, changing the conventional notion of the 'Russian essence' in art" [17].

In fact, Diaghilev stated here his main principle, which can be called anthological: his Russian projects in Europe were organized as a collection of the most illustrative "excerpts" that concentrated that "Russian essence" in painting, music and theatre. This was the aim of Diaghilev's anthology of Russian music[18], which followed the exhibition anthology of Russian painting and consisted of the Russian Historical Concerts of 1907 and then the opera season of 1908. It is noteworthy that to better bring out the "Russian essence" Diaghilev acted both as director and editor, not only arbitrarily combining, but also drastically changing the selected excerpts. In her article about the music of Ballets Russes, Irina Vershinina analyses how Diaghilev created his own concept of an "authentic Russian" musical performance, sometimes quite freely editing the scores of Rimsky-Korsakov and Mussorgsky. For the production of the opera Boris Godunov in 1908, he changed RimskyKorsakov's generally accepted version of Mussorgsky's original score, and when staging Khovanshchinain 1913 focused on the innovative nature of the opera as a choral performance. "The 'choral opera' was something unheard-of in Europe and became a veritable triumph of the Russian choir in Paris and London" [19].
An integral part of Diaghilev's artistic strategy, both as a director and an impresario, was the desire to take into account and then shape the perception of the Ballets Russes by the European audience, changing the Western concept of the "Russian essence". In this respect, of great interest are Diaghilev's letters to Rimsky-Korsakov, urging the composer, after the success of the "Russian Historical Concerts" and on the eve of opera premieres, to adapt the score for the Paris audience.

Our main goal and, importantly, our main concern will be to make Paris judge our best operas by their great merits. True, Paris is somewhat ready for it, but one shouldn't forget that even such an impatient person as Wagner thought twice about staging Tannhäuser in Paris and even ... revised it for Paris. I can already see you wince, you are already greatly displeased and say that we should not "play up to the French". You're right. But to be a good lecturer one must know one's audience and not disdain those he addresses ... I have dealt with works of art all my life, and I don't think I have harmed them by putting them into different kinds of frames; so our favourite operas should be put in those frames through which the international public in Paris would see them not only without getting tired ... but, on the contrary, with that greed with which it sat at all the concerts [20].

In another letter, Diaghilev writes about the coronation scene, which seemed to him especially important: "The coronation scene should be staged in such a way that the French would go mad because of its greatness" [21].

It is important to emphasize the following: the conscious effort to look at oneself from the outside, or the ability to insert works of art into "suitable frames", as Diaghilev himself put it, was not unique to Diaghilevas an impresario of genius, but was also an inherent feature of "World of Art" westernism (and, in part, Russian westernism as a whole), which inspired Diaghilev and became a breeding ground for the future Ballets Russes. At first glance it seems to be a paradox that it was the "World of Art", the most consistent Russian westernisers in the field of fine arts, who created such an integral mythological image of Russian culture that the prewar Diaghilev seasons represented. However, there is undoubted logic here. It is the same consistent pattern as before, when the magazine's pro-western agenda gave rise to Diaghilev's best Russian exhibitions.

Let us recall YuryLotman's well-known statement that the West for the pro-western Russian artist is in many respects "only an ideal point of view rather than a cultural and geographical reality" [22].Although the "World of Art" artists were well-versed in European art, their pro-Western attitude was, above all, an ideal point of view born of the need continuously to position themselves as outside observers. Just as in Russia they created fantasies on the theme of the gallant epoch, so, having moved to Europe, Bakst or Benois just as conventionally "constructed" an imaginary world of the special and unique Russian civilisation. Furthermore, the traditionally European perception of Russian art as "different yet ours" (the same attitude that Diaghilev felt so keenly and guided so skillfully) further spurred the transformations that were inherent in the 
very nature of the "World of Art" pro-western approach: the myth of Russia for the West became a natural extension of the myth of the West for Russia [23].

It is noteworthy that the oriental, Asian image, which the "World of Art" westernisers imparted to the Russian theme in Diaghilev's early productions - Polovtsian Dances (1909) or Scheherazade (1910) — perfectly fitted the traditional concept of Russian anti-Westernism. According to this mythologeme, which goes back to romanticism, the old and dying West is opposed to the young and strong East. Soon, Alexander Blok would write the famous "We are the Scythians! We are the ... Asians!" and in the 1920s the "Scythians" group would bring about a new turn of the same theme: Russia's mission, according to RazumnikIvanovRazumnik, is to "blow up the old world of Europe from within with her 'Scythianism' and her spiritual and social 'maximalism"' [24].Meanwhile, Diaghilev's Ballets Russes "blow up from within" the prewar world of European culture - completing by 1915 the first "exotic" stage of the presentation of Russian culture, which, according to Robert Brussel, had to be covered "especially quickly".

The post-war period of the Ballets Russes was a logical continuation of this endeavor — the pro-Western "Russian project" of the "World of Art" movement naturally fit in with Larionov's and Goncharova's anti-Western attitudes. The famous opera-ballet The Golden Cockerel (Le Coq d'Or, 1914) conceived by Benois and designed by Goncharova and Larionov, marked the change of epochs in the history of Diaghilev's enterprise. Their work could not have better suited Diaghilev's strategic task of another time, the task of putting Russian art in the Western context no longer as something "different" and exotic, but as its inalienable part and, what is more, as an instrument opening new ways of development and thereby setting a new direction for Western art itself. One of the vectors of such innovations was the creation through art of a modern formula of national identity - an important issue for Europe, which survived the First World War and once again turned to problems of national self-identification. In the face of the world catastrophe and then the Russian revolution, the question of the boundaries of one's own integrity arose inevitably.

Turning to Russian folklore in the ballets of the second half of the 1910s - early 1920s was such an attempt to define these boundaries, to offer a modern interpretation of the deeply-rooted national traditions. In Larionov's and Goncharova's milieu, immersion in folk art was considered the surest way to awaken the national memory of culture and revive its archetypes, pervasive motifs and world outlook itself. These ideas inspired Diaghilev, too: in an interview with British critics[25], he speaks about the folk sources of the Russian music school and about the "point of departure" of his new productions - national art taking the form of folk dances in ballets [26].Diaghilev's and Larionov's fascination was picked up by Massine, who wrote about "folk" ballets that "it was thanks to Larionov" that he "first came to understand the true nature of these old peasant ritual dances" [27].
In 1910, The Firebird was the first experience in staging a ballet based on Russian folklore. Initially, Anatoly Liadov, the author of the symphonic pieces Kikimora, Baba Yaga, and The Enchanted Lake and numerous arrangements of Russian songs, was to compose music for the ballet. But he was behind the schedule, and after many vicissitudes Diaghilev turned to the young and as yet unknown composer Igor Stravinsky. As a result, The Firebird became not only one of Diaghilev's most famous ballets, which marked the beginning of the folklore line of the Ballets Russes, but also, according to Irina Vershinina, "a kind of musical encyclopaedia of the basics and achievements of Russian classics, a masterful embodiment of Diaghilev's anthological principle in one work... Rimsky-Korsakov, Tchaikovsky, Borodin, Mussorgsky, Liadov, and Glazunov found their reflection(s) in the sound structure of the ballet, but in their distinctive creative individualities Stravinsky grasped the common features of the distinctive Russian style and conveyed the general feeling of the entire musical epoch"'[28].

In 1916, Diaghilev again decided to turn to the theme of Russian folklore - remembering, apparently, Liadov and his fairytale miniatures. This is what Massine wrote about the beginning of his work on the ballets: "Diaghilev suggested that Larionov and I should make use of one act of Kikimoraas a starting point for creating a ballet that would bring together various Russian legends, again to Liadov's music. Of all fairy tales and folk legends, we finally settled on the stories about Baba Yaga and decided to call the ballet Children's Tales". [29] The suite Children's Tales (Contes Russes), which included, beside Kikimora and Baba Yaga, the miniatures Bova Korolevitch and the Swan Princess, was performed by the Ballets Russes de Diaghilev on 11 May 1917 in the Théâtre du Châtelet in Paris. The final version (with miniatures The Swan Princess, Kolinda-Maleda, and The Burial of the Dragon) was performed on 23 December 1918 at the Coliseum Theater in London.

Just as Stravinsky's The Firebird became an avant-garde interpretation of Russian classical music, Diaghilev is now after a "modernised folklore form", as he put it. The Midnight Sun (Soleil de Nuit), a one-act ballet set to Rimsky-Korsakov's music from the opera The Snow Maiden, became the production that marked a departure from the Oriental mythologeme and the birth of new aesthetics. The Midnight Sun was Larionov's and Massine's first experience of joint work. It premiered in December 1915 in Geneva, but the new version was shown to the public, just as the Children's Tales, in the Coliseum in London in November 1918. Together with The Buffoon (Chout) to Prokofiev's music, which was conceived in 1915, but presented to the public only in 1921, and two more ballets by Stravinsky, Le Renard and Les Noces, the ballets made an impressive "folklore" compendium, designed by Larionov and Goncharova.

\section{ROGER FRY ON LARIONOV AND MASSINE FOLKLORE VERSUS FUTURISM}

Roger Fry devoted most of his article "M. Larionov and the Russian Ballet" to the London productions of Midnight 
Sun and Children's Tales. Scholars have described many of the designs for these ballets. I will only point out the motifs singled out by Fry as graphic examples of an innovative concept of Russian ballet choreography and scenography.

Fry opens his article by stating that the décor offered by Larionov and Goncharova helps to bridge the gap between the innovative music and choreography, on the one hand, and rather archaic scenography, on the other, of the Ballets Russes productions starting with Le Sacre du Printemps. Ruhrich's scenery that, according to Fry, was of the bygone era was a poor match for the musical experiments of Stravinsky. The new ideas of Massine were an even greater challenge for the artists. Fry calls his choreographic style "heraldic": its movements are rendered within definitely restricted silhouettes. This concept is aptly matched by Larionov's costume designs, in which "both form and colours underline and support the movement" and provide "a formal equivalent" to the "choreographic design". With Midnight Sun and Children's Tales productions, according to Fry, "the harmony of the three arts" that distinguished Diaghilev's early ballets "was once more established".

Indeed, the choreographer and the artist each took a step in each other's direction when Massine and Larionov started their collaboration. Massine's style was guided by pictorial imagery to a far greater extent than that of Fokine or Nijinsky while Larionov was the only artist of Diaghilev's Ballets Russes collaborators to be involved directly in choreography. Massine had been trained in arts and decided to choreograph ballets under the impression of the Uffizi collection he saw on his tour of Italy. It is not by chance that Elizabeth Souritz, who had researched Massine's oeuvres, suggested that his theatre should be called "painterly" because his choreography is closely linked with pictorial sources. The very "choreographic text" of Massine's early ballets staged with the help of Larionov and, doubtlessly, under his influence took shape as a sort of stylisation of Larionov's painterly methods. Souritz notes, "Massine used the same methods as the artist did when creating a picture reproducing lubok or any other primitive style. $<\ldots>$ What we have here was the deliberate coarsening of postures and movements, when the choreographer moves away from the classical ideal and comes close to ethnographical dance, $<\ldots>$ that is, resorts to stylisation, akin to painterly stylisation" [30].

Now while Massine's choreography evolved toward greater picturesqueness, Larionov, on the contrary, gradually renounced painting for the sake of purely choreographic experimentation. The motifs of primitivist painting and pictorial folklore that made their way into the Russian ballets due to his impact foreshadowed and predetermined the subsequent connection between dance movements themselves and folklore sources. Evgenialliukhina writes the following about Le Bouffon ballet choreography that Larionov masterminded almost entirely on his own, "The dances were based on folklore movements that Larionov studied in all seriousness, gradually accumulating the visual material - drawn copies of reliefs, manuscript miniatures showing buffoon dances and photographs of ritual dances performed by peasants" [31].
The unique blend of painterly and choreographic folklore sources, the early signs of which appeared before Le Bouffon production and which became the trademark of the Larionov-Massine tandem was, in all likelihood, responsible for the Russian ballet style that Fry called "heraldic". Evidently, it was not merely a matter of seeking to "lock" the movement into some silhouettes or forms borrowed from pictorial sources, but above all making these recurring forms recognizable. Souritz writes about Larionov's collaboration with Massine, "Massine discussed with him every position, trying to attain laconism and simplicity in movements and groupings that would correspond to both ancient painting and the manner of primitivist artists" [32].

The rhythmical alternation of these "positions" and "groupings", like a sort of national ornament, becomes the plastic formula of national art. This sort of ornamentality is also noticeable in the choreographic patterns that Larionov developed and in the surviving ballet photographs. For instance, one can see in the photograph of the maid servants of The Swan Princess (a ballet from the Children's Tales suite) that the bends and symmetrical movement of the arms produce a wavy line, repeating the headgear outlines and simultaneously framing the sarafan pattern work. The strictly marked out phases of these movements locked in the rhythmically recurring outlines produce the impression of a live ornament appearing and altering in front of one's eyes. The same ornamentality is seen in Midnight Sun photographs. Fry makes special mention of this rhythmicity of silhouettes and movements, "The formal relations of movements in all the different parts of the ballet have become more and more distinct and evident - the whole pattern is keyed up to an intenser unity and the intellectual quality of the design is further intensified" [33].

Obviously, these were the qualities of his choreography that Massine described in The Observer interview that closes a detailed article entitled "Massine's Ballets. Emancipation from the Classic School. Body Dancing". Massine speaks about the new "choreographic gesture", contrasting it with the mimetic gesture of the old school. The new gesture is not after imitating "mundane movement" but seeks a purely pictorial form based on "liberated rhythm". "Choreography is freeing itself from every kind of restraint and establishing its independence. It has, moreover, all the means within itself. It has, for example, rhythm (...) and it has outline, or, if you prefer to call it so, draughts manship. The choreographic silhouette is in itself a drawing."[34]

According to Massine, the rhythmic replication of such drawings produces a new type of ballet that is a sort of choreographic ornament. This enthusiasm about rhythm as a means for the ideal organisation of "collective bodies" is in line much more broadly with the popular ideas of the time. What is more, it carries on the endeavours of Diaghilev, who in 1913 went to Hellerau to study the method of Emile Jaques-Dalcroze and who hoped to use it in choreography. Larionov formulates similar ideas in the form of succinct theses in Albomnyezapisi M.F. Larionova (1917-1919) (Album Notes of M.F. Larionov. 1917-1919) and subsequently expands them in lengthy passages in his numerous articles on the theatre written in the 1920s through 
the 1930s [35].These theses included: "Gesture as form and as movement", "discipline in gesture, rhythmic gymnastics", "a sense of movement, form, and mass of group scenes. A sense of how a group is drawn - Development in the movement of the drawing and form of group scenes - static scenes as one of the forms of movement" [36].

Later on Larionov would describe in detail what the fundamental difference was between "Massine's style" and his own productions in collaboration with Massine, on the one side, and the choreography of other mâitres de ballet, including those of the Diaghilev enterprise, on the other. Their choreographic style is not based on a mere alternation of plastic figures reproducing sculptural forms of Ancient Greece, as Michel Fokine had it, or postures on Greek painted vases as those of Isadora Duncan, but on the rhythmically organized and "lasting" movement that naturally arises from every preceding position. "Lasting movement is what Massine excelled in. If the choreographer does not possess this ability in full measure to organize a mass dance, he won't be able to really convey this continuous movement, the continuous evolution of steps and postures that dance is after all" [37].

Obviously, the "painterly theatre" of Massine and Larionov, based on the combination of plastic and dance folklore sources and united by the rhythmic "drawing of mass groupings", was precisely the "modernized form of folklore" that Diaghilev sought. However, "modernization" was not only confined to the new concept of choreography aptly called "heraldic" by Fry. The key mechanism of innovation was the system of artistic Futurist techniques developed by Larionov in his concepts of the Futurist theatre from 1913 on. Although folklore was the theme and source of ballets such as Midnight Sun and Children's Tales, they were staged according to Futurist principles. When Fry writes, “...one secret of M. Larionow's success lies precisely in this fact, that for him the movement of the figure, whatever it be, is the fundamental fact of his design", [38] he actually formulates the key idea of Larionov that he kept varying in his own texts. The pithiest definition of the decorator given by Larionov is as follows: he is "an artist who creates a costume and background in accordance with movement. And ties movement with the costume and costume with the background" [39].This "fundamental", according to Fry, principle leads to the weakening of the plot of the ballet story and the shift of emphasis from the plot to the choreographic and decorative solution of the performance. In fact, neither Midnight Sunnor Children's Tales has a plot. In the former ballet the lyrical story of the Snow Maiden is relegated to the background and action is based on pagan rites and ritual dances to see off winter and welcome Jarilo the Sun. The series of choreographic miniatures of Children's Tales is united not by a single plot, but by the imitation of the form of folklore narrative and the presentation of the diverse genres of Russian folklore, including the tale, ballad, heroic poem and anecdote [40]. The scenography and choreography of the two productions are a sort of anthology of Futurist theatre techniques, from moving sets to Futurist makeup, and have much in common with projects of Giacomo Balla, Fortunato Depero or Enrico
Prampolini's "Manifesto of Futurist Scenography and Choreography" [41] that, just as Midnight Sun[42],appeared in 1915.

Fry sees precisely the poignancy of such combination of the "traditional" and "national", on the one hand, and experimental forms, on the other, as the chief accomplishment of Larionov as a stage designer. "And herein we find one of M.Larionov`s peculiarities, his use of entirely modern discoveries in design with a certain retrospective allusiveness to the arts of other times and countries (...) It is this power of using form and colour with a double meaning, first as pure design, and secondly as a means of evoking vague suggestions and flavours of time and space, that makes him so consummate a designer for the theatre." [43]

Such a combination distinguished already Midnight Sun, the first production of Larionov and Massine. The rotating solar disk was the central motif of the integral choreographic and artistic concept. Solar signs in the sets and costumes (headgear consisted of round disks and the "red-cheeked buffoon with a tambourine" performed by Massine had shining "suns" on his arms) conformed to intricate rhythms reminiscent of Cubo-futurist compositions. The solar disks on the top masking border rotated fiercely and their rhythm was carried on by the disks on the dancers' arms, creating a multi-dimensional picture of intersecting circular movements of the gold and red gamut against a dark blue backdrop that likewise referenced traditional solar symbolism. The spectacle imagery was at the junction of the archaic, mythical archetypes and futurist rhythms.

Sets and costumes for Children's Tales were even more pronouncedly futuristic. It was the peak of Larionov's fascination with the ideas of moving sets that transformed in front of the spectators' eyes. The sets for Baba Yagabrimmed with moving elements: the flowers swayed, the hut broke into a dance and a part of the sets "came to life", transforming into a forest spirit. The sets design composition for Baba Yaga's enchanted forest was based on the intersecting diagonals and varicoloured arcs reminiscent of the "reified" beams of the coloured spotlights from Prampolini's manifesto of new futurist scenography. Another less known design of a phantom forest shows a Rayonist décor, in which the red trunks and bluish green "Rayonist" crowns of trees seem to be a direct illustration to Prampolini's description, "With the luminous irradiations of these beams, of these planes of coloured lights, the dynamic combinations will give marvelous results of mutual permeation, of intersection of lights and shadows." [44] Futurist makeup, too, became part of this action enveloped in continuous movement. In their famous manifesto "Why We Paint Ourselves" of 1913, Larionov and IlyaZdanevich called for painting faces in order to attune the new "multiplied man" to the changing rhythms of the modern city; meanwhile now the futuristic makeup in the theatre, fully substituting the mask for the face, was called upon to involve the actor of a new type in the rhythmic colour action that the modern ballet was to become. 
In the second part of his article Fry focusses on Larionov's interest in the coloured shadow theatre (La Marche funèbre to music of Lord Berners, 1919) and the marionette theatre (Histoiresnaturelles) where, according to the critic, "the designer reigns supreme, where the performers are his own handiwork and display an unfailing obedience to his wishes". Describing Larionov's designs for the unrealized production of Histoiresnaturelles to music by Ravel, with libretto by Jules Renard and Larionov, Fry compares them, on the one side, with designs of Pierre Bonnard for the libretto by Renard and, on the other, with the structured costumes of Pablo Picasso [45].Strangely, Fry never mentions Depero: the similarity between the "mechanical figures" from Histoiresnaturelles and Depero's marionettes was so obvious that it provoked a scandal and charges of plagiarism against Larionov. Instead of drawing a direct parallel with Depero, Fry compares Larionov with Bonnard, whose designs for this ballet, albeit an indisputable success, still belong to the preceding artistic period, and pays his own homage to Larionov by asserting his supremacy in designing innovative futurist productions. Fry commends Larionov's futurist Rayonist stage designs "as a curious and rather unexpected outcome of certain researches into purely abstract form" and closes his article with the following acclaim, "M. Larionov appears to have made most entirely his own the study of movements and the methods of adapting forms to its completest expression. It is this no doubt that has drawn him to the ballet, and it is this that has enabled him to place almost for the first time in modern history a real work of visual art within the frame of a proscenium" [46].

Le Bouffon ballet to Sergei Prokofiev's music became a sort of manifesto of "folklore form" modernised along futurist lines [47].Just as in Children's Tales, décor was made of movable elements constructed and changed in front of the spectators' eyes. The curtain, designed by Larionov in France in 1915, comes across as a sort of programme declaration. It showed the national sources of modern Russian and European art - a Scythian "stone idol" and mediaeval sculpture, as well as the national architectural symbols as represented by St. Basil's Cathedral and NotreDame de Paris compositionally united by Cubo-futurist rhythms, "shifts" and overlapping planes. The contours of new modernist art were virtually born of the visible outlines of the art of the past. The attributes of the clown and skomorokh at the bottom of the curtain brought to mind the mediaeval sources of modern theatre and partially transformed a ballet of tomfoolery into a story of the theatre about itself and a gameplay study of the nature of theatricality. At the same time, it was a visual illustration of Larionov's postulates from his notes on the history of the theatre, which assigned a special place to Russian farce, skomorokhs, mummers, etc. Overall, such nearly mocking parallels in a prankish production were in fact a direct and visual metaphor of the deeply-rooted inherent traditions responsible for the specifics of the national varieties of modern art and a declaration of their differences.

\section{CONCLUSION}

This type of declarativity was easily detected by English critics and at times unexpectedly echoed their own thoughts about native art. The theme of the deeply rooted features of culture conditioned by specific geographic, climatic and historical features was current in English futurism of that period and the programmatic articles of Wyndham Lewis [48]. In this context both Fry and Wyndham Lewis in his Blast magazine reviews tended to consider modern Russian art, graphically exemplified by works of Larionov and Goncharova, as a sort of model version of modernism addressing precisely the primordial immutable characteristics and, through them, the memory of native culture.

The mythology of Russian "folklore" ballets linked to the theme of northern lands gained importance within the framework of those ideas. Starting with Midnight Sun, northern motifs went side by side with the eastern mythologeme in the interpretation of the Russian theme, gradually squeezing it out. GlebPospelov wrote about the erroneous translation of the very title Polunochnoye solntse, due to which the traditional Russian meaning of the word polnoshchnyi, that is, northern, was distorted. Instead of the original meaning "The Sun of the North" or "The Sun of the Northern Lands", the title "Polnoshchnoye solntse" was thought to be an oxymoron and translated as Soleil de minuit and later even as Lesoleil de nuit. Due to a mistake in the original translation, the ballet went down in history under the name of Midnight Sun. "In fact, Jarilo the Sun dancing in the midst of the Berendei crowd is not the Sun of the Night, but the Sun of the North." [49] Despite the translation mistake the more perceptive of the English critics discerned the northern motifs of the Berendei Rus' as an extremely important theme of the production.

Within the British discourse on the search of inherent traditions that determined the different world outlooks and cultures Russian art was often associated typologically with the cultures of "northern lands"[50] that primordially did not fit into the "Mediterranean" community. The symbolism of "polnoshchnykh" (northern) countries and relevant mythical archetypes, on which Russian folklore ballets were based, were perfectly in line with this northern mythology. In this sense Russian modernism served as a possible loadstar for British modernism, for which the inherent memory of culture contrasting itself with that of Europe, the Mediterranean one, was likewise a structural theme. For Diaghilev's Ballets Russes, an integral project running over two decades, Russian folklore ballets marked a logical stage of integration into European culture.

I would like to conclude with an echo of Larionov's Homage to Roger Fry that signified a curious meeting point of Russian and English art. Both Fry and Lewis made attempts to collaborate with Diaghilev and the Russian ballet company. In a 1918 letter to Vanessa Bell, Fry writes about his meeting with Diaghilev and a possible commission for the Omega Workshops to design sets and costumes for the Ballets Russes. A year later Lewis, too, planned to offer Diaghilev his contribution to the ballet décor. Although the two projects failed to materialise, their very possibility is a 
remarkable illustration of the historical attitude of British artists and critics to Russian art and the Ballets Russes.

\section{REFERENCES}

[1] E. Vyazova. Mikhail Larionov's Homage to Roger Fry: RussianEnglish Parallels in the History of Sergei Diaghilev's Ballets Russes", Iskusstvoznanie, № 4(17), 2017, pp.140-174.

[2] Homage to Roger Fry, 1919, Collage and Watercolour on Paper, 25.2 x 20, Victoria \& Albert Museum, London. Inv. R. 43-1984.

[3] A. Parton. Mikhail Larionov and the Russian Avant-Garde. Princeton: Princeton University Press, 1993, p. 174

[4] "Russian Exhibition, Descriptive of the Industries, Art, Literature and Customs of Russia" in Grafton Galleries, May 1917; "Exhibition of Sketches by M. Larionow, and Drawings by the Girls of the Dudley High School at Omega Workshops", February 1919; Rerikh's Spells of Russia at the Goupil Gallery, May 1920.

[5] H.G. The Return of the Russians. Ballet as Spectacle, The Observer, May 29, 1921, p. 7.

[6] See note3.

[7] R. Fry. M. Larionov and the Russian Ballet, Burlington Magazine, 1919, vol. 34, no. 192, pp. 112-118.

[8] With the exception of a brief tour of Manchester on 7-19 April 1919.

[9] It is noteworthy that Larionov and Fry never met in person for eight years until 1920

[10] "The Omega Workshops: Alliance and Enmity in English Art, 19111920". London: Anthony d'Offay Gallery, 1984, p. 22, no. 80.

[11] A. Parton. Op. cit., p. 175.

[12] Hans Arp. Fleur Marteau(1916, Arp Foundation, Clamart)

[13] G.G. Pospelov, E.A Ilyukhina. Mikhail Larionov. Moscow: Galart, RA, 2005,p. 151.

[14] Mikhail Larionov's album notes (1917-1919) in G.G. Pospelov, E.A. Ilyukhina, Op. cit., p. 331

[15] "The Russian Ballet. How It Was Created". Interview with M. Serge Diaghileff in The Observer,25 May 1919, p. 7.

[16] S. Lifar, Serge Diaghilev, His Life, His Works”. London: Putnam, 1945, p. 215.

[17] Cit. A. Tolstoy, "Russkoye iskusstvo: zarubezhnye marshruty" (Russian Art: Foreign Routes) in Russkoye iskusstvo, no.3, 2004. URL: http://www.russiskusstvo.ru / journal /3-2004/ a203 /(accessed 10.10.2017).

[18] I. Vershinina. "Diaghilev and Music of Ballets Russes" in Iskusstvo, no. 12, 2002. URL: http://art.1 september.ru/article. php? ID = 200201202 (date of reference (?) 10.10.2017).

[19] Ibid.

[20] N.D. Chernyshova-Melnik, Diaghilev, Moscow, 2011. Cit.onlineversion https://profilib.net/chtenie/117952/nataliyachernyshova-melnik-dyagilev.php

[21] N.D. Chernyshova-Melnik. Op. cit.

[22] Y.M. Lotman. The Symbolism of St. Petersburg and Problems of Urban Semiotics in Y.M. Lotman, Selected Articles in 3 Volumes, Tallinn, 1992, Vol. 2, p. 17.

[23] G.G. Pospelov. "Rossia glazami dyagilevskikh sezonov (Russia Through the Eyes of the Diaghilev Seasons)" in Literary Pantheon: National and Foreign. Materials of the Russian-French colloquium, Moscow, 1999. Reprinted from The Pinakotheke, nos.13-14, 2002, pp.106-111.

[24] E. Bobrinskaya. "'Memory of Culture' and the Anti-Western Utopia of Russian Futurists" in Memory as an Object and Instrument of Art Studies, Moscow: State Institute of Art Studies, 2016, p. 359

[25] "Cimarosa at Covent Garden. Italian Opera and Russian Ballet. M. Diaghileff's Theory of Acting" in The Observer, 20 June, 1920, p.10; "The Three-Cornered Hat. The new Russian ballet. M. Diaghileff and Plans for the Future." in The Observer, 20 July, 1919, p. 6
[26] E. Iliukhina. "Mikhail Larionov i Natalia Goncharova v antreprize 'Russkij ballet SergeyaDiaghileva"" (Mikhail Larionov and Natalia Goncharova in the Ballets Russes de Diaghilev) in Vision of the Dance. Sergei Diaghilev and Russian Ballet Seasons / Catalogue of the exhibition at the State Tretyakov Gallery. Moscow, 2009, p.83.

[27] G.G. Pospelov. E.A. Iliukhina, Op. cit., p. 189.

[28] I. Vershinina. Diaghilev and the Music of the Ballets Russes..

[29] Cit. N.D. Chernyshova-Melnik. Op. cit.

[30] E.Ia. Souritz. The Painterly Theatre of Leonide Massine, Saint Petersburg: Dmitry Bulanin, 2000, p. 263.

[31] E. Iliukhina. Op. cit., p. 83. "Mikhail Larionov and Natalia Goncharova in the Ballets Russes de Diaghilev" in Vision of the Dance. Sergei Diaghilev and Russian Ballet Seasons / Catalogue of the exhibition at the State Tretyakov Gallery. Moscow, 2009, p.83.]

[32] Cit. G.G. Pospelov, E.A Iliukhina. Op. cit., p. 194

[33] R.Fry. Op. cit., p. 117.

[34] Massine's Ballets. "Emancipation From the Classic School. Body Dancing" in The Observer, 27 July 1919, p. 6.

[35] Cit. G.G. Pospelov, E.A. Iliukhina. Op. cit., p. 355.

[36] Notes of M.F. Larionov. 1917-1919 in G.G. Pospelov, E.A. Iliukhina, Op. cit., p. 329.

[37] Dance (1930s - 1940s) in G.G. Pospelov, E.A. Iliukhina. Op. cit., p. 351.

[38] R. Fry. Op. cit., p. 117.

[39] Cit. G.G. Pospelov, E.A. Iliukhina. Op. cit., p. 195.

[40] Ibid., p. 210

[41] Manifestos and Programmes of Italian Futurism 1913 - 1933 / Introduction, Editing, Translation from Italian and Commentary by Ekaterina Lazareva. Moscow: Hylaea, 2013.

[42] "Larionov's Rayonism as a Precursor of Kinetic Art"// G.G. Pospelov, "On Pictures and Drawings". Moscow: Novoyeliteraturnoyeobozreniye, 2013, pp. 330-331

[43] R. Fry. Op. cit., p. 117.

[44] Prampolini, E. "Manifesto of Futurist Scenography" in Twentieth Century Theatre: A Sourcebook. Ed. Richard Drain. New York: Routledge, 1995, p. 23.

[45] Apparently, Fry had in mind the famous ballet Parade, designed by Picasso and staged by the Ballets Russes de Diaghilev in 1917.

[46] R. Fry. Op. cit., p. 118

[47] "Mnemosyne: Documents and Facts From the History of Russian Theatre of the Twentieth Century". Issue 6. Executive editor V.V. Ivanov. Moscow: Indrik, 2014.

[48] The Manifesto of Wyndham Lewis on Modern English art (Blast, No. 1, 1914. London: John Lane)

[49] G.G. Pospelov. Russian Art of the Early Twentieth Century TheDestiny and Image of Russia. Moscow, 1999, p. 124

[50] Beasley R. "Vortorussophilia" in Vorticism. New Perspectives Edited by Mark Antliff and Scott W. Klein. Oxford University Press, 2013 